\title{
Rendimiento y valor nutritivo de leguminosas forrajeras en dos épocas del año y cuatro edades de rebrote
}

\section{Yield and nutritive value of forage legumes in two seasons and four regrowth stages}

\author{
Lidia García-Ferrera, Eduardo Daniel Bolaños-Aguilarb, J esús Ramos-J uárezc \\ Mario Osorio Arcec, Luz del Carmen Lagunes-Espinozad
}

\begin{abstract}
RESUMEN
El efecto de edad de rebrote (21, 42, 63 y 84 días) sobre el rendimiento de materia seca (RMS), proporción de hoja (PH) y valor nutritivo de cacahuatillo (Arachis pintoi), stylo (Stylosanthes guianensis), clitoria (Clitoria ternatea) y kudzú (Pueraria phaseoloides), se evaluó durante la época seca (marzo-mayo) y lluviosa (junio-agosto) de 2013. El RMS y la fibra detergente neutro (FDN) se incrementaron con la edad, mientras que la PH, proteína (CP) y degradabilidad disminuyeron. Cacahuatillo y stylo registraron los RMS más altos en las dos épocas; en promedio 5.5 y 7.5 t ha-1 a los 84 días en época seca y lluviosa, respectivamente. En ambas épocas, la mayor y menor PH fueron para cacahuatillo y stylo, respectivamente. En CP, clitoria y cacahuatillo presentaron las mayores en ambas épocas; superiores a 140

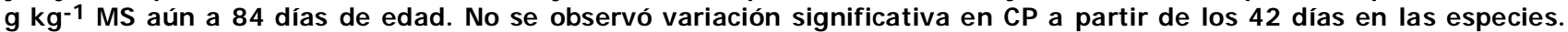
A los 21 días, stylo (704.7 $\mathrm{g} \mathrm{kg}^{-1} \mathrm{MS}$ ) en la época seca y kudzú (658.4 $\mathrm{g} \mathrm{kg}^{-1} \mathrm{MS}$ ) en la época lluviosa presentaron la mayor FDN. No hubo diferencias entre especies a partir de los 42 días. Cacahuatillo tuvo la mayor degradabilidad (>700 $\mathrm{g} \mathrm{kg}^{-1} \mathrm{MS}$ ) durante su crecimiento en ambas épocas. En clitoria, stylo y kudzú sólo fue superior a $700 \mathrm{~g} \mathrm{~kg}^{-1} \mathrm{MS}$ a los 21 días, pero desde los 42 días de edad, la degradabilidad disminuyó. En conclusión, la edad de rebrote que integra mayor RMS y valor nutritivo es la de 42 días en las leguminosas evaluadas, independientemente de la época del año.
\end{abstract}

PALABRAS CLAVE: Arachis pintoi, Stylosanthes guianensis, Clitoria ternatea, Pueraria phaseoloides, Proteína, Degradabilidad, Fibra detergente neutro.

\begin{abstract}
The effect of age of regrowth $(21,42,63$ and $84 \mathrm{~d})$ on the dry matter yield (DMY), leaf proportion (LP) and nutritive value of cacahuatillo (Arachis pintoi), stylo (Stylosanthes guianensis), clitoria (Clitoria ternatea) and kudzu (Pueraria phaseoloides) was evaluated during the dry season (March-May) and rainy (June-August) of 2013. The DMY and neutral detergent fiber (NDF) increased with age, while the LP, protein (CP) and degradability decreased. Stylo and cacahuatillo recorded the highest DMY in both seasons; on average 5.5 and $7.5 \mathrm{t} \mathrm{ha-1}$ at $84 \mathrm{~d}$ in dry and rainy season respectively. In both seasons, the highest and lowest LP were for cacahuatillo and stylo, respectively. High CP was recorded by clitoria and cacahuatillo in both seasons; greater than $14 \mathrm{~g} \mathrm{~kg}^{-1}$ DM even $84 \mathrm{~d}$ old. No significant variation was observed in CP from $42 \mathrm{~d}$ in the species. At $21 \mathrm{~d}$, stylo (704.7 $\mathrm{g} \mathrm{kg}^{-1} \mathrm{DM}$ ) in the dry season and kudzu (658.4 $\mathrm{g} \mathrm{kg}^{-1} \mathrm{DM}$ ) in the rainy season had the largest NDF. There were no differences between species from $42 \mathrm{~d}$. Cacahuatillo had the highest degradability (>700 $\mathrm{g} \mathrm{kg}^{-1} \mathrm{DM}$ ) during its growth in both seasons. In clitoria, stylo and kudzu was just above $700 \mathrm{~g} \mathrm{~kg}^{-1} \mathrm{DM}$ at $21 \mathrm{~d}$, but from $42 \mathrm{~d}$ of age, degradability decreased. In conclusion, the age of regrowth that integrates DMY and better nutritional value is $\mathbf{4 2} \mathrm{d}$ old in the legumes evaluated, regardless of the season of year.

KEY WORDS: Arachis pintoi, Stylosanthes guianensis, Clitoria ternatea, Pueraria phaseoloides, Protein, Degradability, Neutral detergent fiber.

Recibido el 22 de septiembre de 2014. Aceptado el 24 de noviembre de 2014.

a Campus Tabasco. Colegio de Postgraduados (CP). Periférico Carlos A. Molina s/n 86500 H. Cárdenas, Tabasco. México.

b Campo Experimental Huimanguillo, Instituto Nacional de Investigaciones Forestales, Agrícolas y Pecuarias (INIFAP). Km 1 Carretera Huimanguillo - Cárdenas. Huimanguillo, Tabasco. México. Tel. (917) 375-0764, bolanos.eduardo@inifap.gob.mx. Correspondencia al segundo autor

c Área de Ciencia Animal. CP. Cárdenas, Tabasco. México.

d Área de Ciencia Vegetal. CP. Cárdenas, Tabasco. México.
\end{abstract}


Las praderas en la región tropical de México (trópico seco y húmedo) ocupan una superficie de 12 millones de hectáreas, producen 81 millones de toneladas de materia seca y mantienen a un tercio del hato ganadero del país, bajo el sistema de pastoreo y en menor grado combinado con estabulación(1). En el trópico húmedo, la producción animal (carne, leche, becerro) del estado de Tabasco se obtiene principalmente del pastoreo de praderas permanentes. Por esta razón, el dominio del manejo de praderas y el uso de pastos de mayor producción de materia seca y calidad, son un factor importante para la productividad y sustentabilidad de los sistemas de producción pecuaria en esta entidad. Sin embargo, las gramíneas forrajeras tropicales son comúnmente de bajo valor nutritivo, particularmente en proteína. Dependiendo de la época del año, edad de rebrote y especie, el contenido de proteína en los pastos varía de 6 a $14 \%$, y en algunos casos contienen menos del $6 \%(2)$. Esta baja concentración en proteína afecta la productividad animal, por requerir el rumen un mínimo de $7 \%$ de este nutriente para su óptimo funcionamiento(3), lo que aunado a la estacionalidad de producción de forraje, limita la sustentabilidad de la productividad animal a través del año(4).

Una alternativa para mejorar la dieta del animal en pastoreo y mantener la sustentabilidad del sistema, es introduciendo leguminosas forrajeras en la pradera sea en asociación o en bancos de proteína. Las leguminosas fijan nitrógeno al suelo, lo cual puede beneficiar a la gramínea asociada y proporcionan un alimento de alta calidad y económico. El contenido de proteína y de minerales de las leguminosas es muy superior al de las gramíneas(5), aunque se ha observado que las primeras también presentan variaciones en sus contenidos al comparárseles entre regiones secas y húmedas(6). Existe información suficiente sobre el rendimiento de materia seca de las leguminosas forrajeras tropicales al final de un periodo y a diferentes intervalos de corte $(7,8)$. Sin embargo, es escasa la información disponible sobre el momento
Grasslands in the tropical region of Mexico (dry and humid tropics) occupy an area of 12 million hectares, producing 81 million tons of dry matter and with one third of the country's cattle herd under the grazing system also combined with stabling(1) but to a lesser extent. In the humid tropics, animal production (meat, milk, calf) in the state of Tabasco is obtained mainly from permanent grassland grazing. For this reason, the dominance of pasture management and use of pastures with a higher production of dry matter and quality are important for productivity and sustainability of livestock production systems in this region. However, tropical grasses are commonly of low nutritional value, particularly protein. Depending on the season, regrowth age and species, the protein content in pasture varies from 6 to $14 \%$, and in some cases contain less than $6 \%(2)$. This low concentration in protein affects animal productivity, by requiring the rumen to be at least $7 \%$ of this nutrient for optimal functioning (3), which together with the seasonal forage production limits the sustainability of animal productivity through the year(4).

An alternative to improve the diet of grazing animals and maintain sustainability of the system is introduced forage legumes in the pasture or in association or in banks of protein. Legumes fix nitrogen in the soil, which can benefit the associated grass and provide high quality and economic food. The protein content and minerals in legumes is much higher than grasses(5), although we have observed that the former also have variations in content when compared between humid and dry regions(6). There is sufficient information on dry matter yield of tropical forage legumes at the end of a period and at different cutting intervals $(7,8)$. However, little information is available about the optimal harvest time considering the greater quantity and quality of forage, since the first increases and second declines with age ${ }^{(9)}$. By understanding this behavior under humid tropical conditions in Tabasco, will allow for designing management schemes for tropical forage legumes to ensure their quantity and quality for animal feeding. 
óptimo de cosecha considerando la mayor cantidad y calidad del forraje, dado que el primero aumenta y el segundo declina con la edad(9). El conocer este comportamiento bajo las condiciones de trópico húmedo en Tabasco, permitirá diseñar esquemas de manejo de leguminosas forrajeras tropicales que aseguren su cantidad y calidad para alimentación animal.

Dado lo anterior, el objetivo del presente estudio fue conocer el efecto de la edad de rebrote de la planta sobre el rendimiento y valor nutritivo de cuatro leguminosas forrajeras en dos épocas del año contrastantes en disponibilidad de humedad.

El presente estudio, se realizó bajo condiciones de campo durante la época seca (marzo, abril y mayo) y de lluvias (junio, julio y agosto) de 2013 en el jardín de recursos genéticos forrajeros del Campo Experimental Huimanguillo (17 $50^{\prime}$ $\mathrm{N}, 93^{\circ} 23^{\prime} \mathrm{O}$ ), del Instituto Nacional de Investigaciones Forestales Agrícolas y Pecuarias (INIFAP) en Tabasco. El suelo es de textura franca con $41.1 \%$ de arena, $24.5 \%$ de arcilla
Given the above, the objective of this study was to determine the effect of regrowth age of the plant on yield and nutritive value of four forage legumes into two contrasting periods of the year in terms of moisture availability.

This study was conducted under field conditions during the dry (March, April and May) and rainy (J une, July and August) seasons in 2013 in the garden of forage genetic resources of the Huimanguillo Experimental Station $\left(17^{\circ} 50^{\prime} \mathrm{N}\right.$, $93^{\circ} 23^{\prime} \mathrm{W}$ ), of the National Institute of Livestock Agricultural and Forestry Research (INIFAP) in Tabasco. The soil was of a loamy texture with $41.1 \%$ sand, $24.5 \%$ clay and $34.4 \%$ loam, $\mathrm{pH} 7.0$ and 21.5 millequivalents $100 \mathrm{~g}^{-1}$ of ion exchange capacity. No fertilizer was applied, nor was irrigation available in the dry period of the year. Climatological data is presented in Figure 1. The biological material consisted of four species of herbaceous forage legumes: cacahuatillo (Arachis pintoi Krapovickas \& Gregory), stylo (Stylosanthes guianensis (Aubl.) Sw.), or Tehuana clitoria (Clitoria ternatea L.) and kudzú (Pueraria phaseoloides Roxburgh

Figura 1. Datos promedio de precipitación pluvial y temperatura durante el período de evaluación en 2013

Figure 1. Average rainfall and temperature data during the evaluation period in 2013

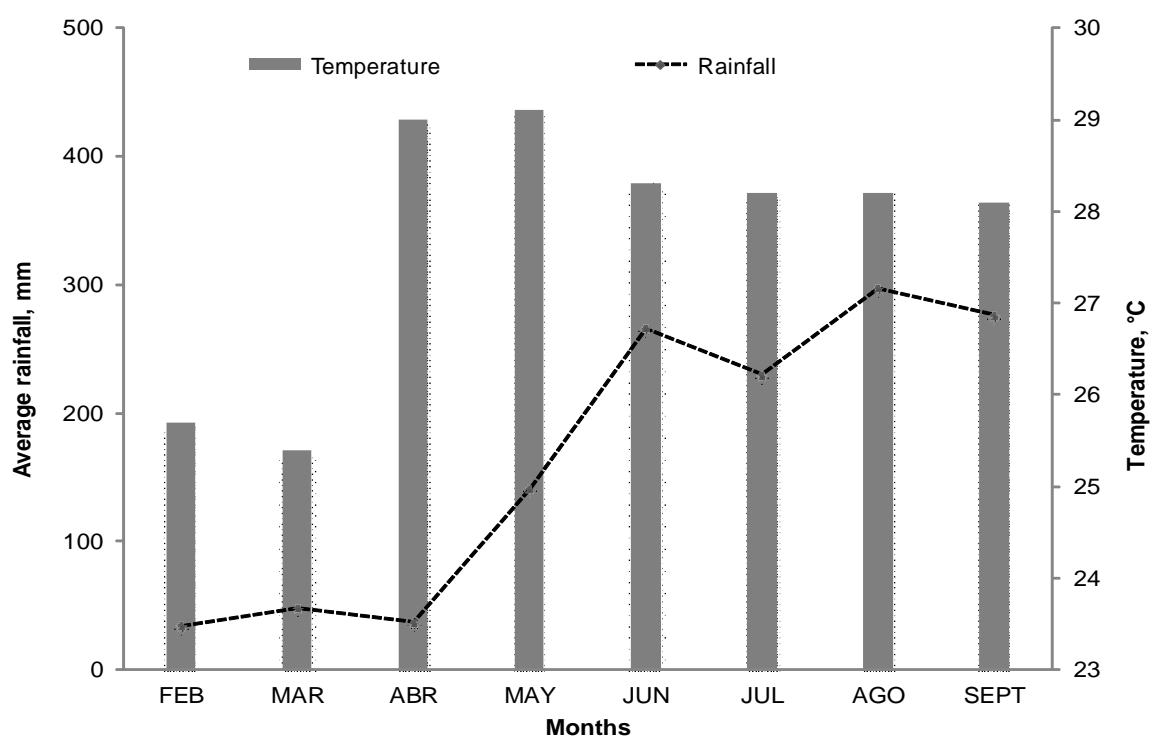


y $34.4 \%$ de limo, pH 7.0 y 21.5 mili equivalentes por $100 \mathrm{~g}$ de capacidad de intercambio catiónico. No se aplicó fertilización, ni se dispuso de irrigación en el período seco del año. Los datos climatológicos se presentan en la Figura 1. El material biológico lo constituyeron cuatro especies de leguminosas forrajeras herbáceas: cacahuatillo (Arachis pintoi Krapovickas \& Gregory), stylo (Stylosanthes guianensis (Aubl.) Sw.), clitoria o Tehuana (Clitoria ternatea L.) y kudzú (Pueraria phaseoloides Roxburgh Bentham). Estas especies se sembraron el 8 de agosto de 2012 en parcelas de $2 \times 4 \mathrm{~m}$, a una densidad de siembra de $5 \mathrm{~kg}$ de semilla ha-1 distribuidos en cinco líneas trazadas a lo largo de cada parcela y separadas a $50 \mathrm{~cm}$, excepto cacahuatillo. Este último se sembró por material vegetativo (tallos con raíz) a una distancia de $25 \mathrm{~cm}$ entre tallo y tallo. Las parcelas se distribuyeron en campo al azar, separadas a $1.5 \mathrm{~m}$ entre ellas y con tres repeticiones por especie.

Cada parcela se dividió en cuatro subparcelas de $2 \times 1 \mathrm{~m}$, a las que se les asignó en forma aleatoria, una de las cuatro edades de rebrote: $21,42,63$ y 84 días. Los días de edad al rebrote se contaron a partir del corte de uniformidad, el cual se realizó a todas las parcelas el 26 de febrero para la época seca, y el 20 de mayo para la época de lluvias. De esta manera las cosechas se realizaron los días 18 de marzo, 8 y 29 de abril y 20 de mayo, para la época seca, y 10 de junio, 1 y 22 de julio y 12 de agosto para la época de lluvias. En cada subparcela (edad de rebrote), se cosechó toda la biomasa aérea o materia verde (MV) con cortes a $10 \mathrm{~cm}$ del nivel del suelo para stylo, y a $5 \mathrm{~cm}$ para las leguminosas restantes. El material colectado se pesaba en báscula electrónica portátil con capacidad de $10 \mathrm{~kg} \pm 1 \mathrm{~g}$. Para determinar el rendimiento de materia seca (RMS, t ha-1), se separaron submuestras de $300 \mathrm{~g}$ de MV, las que se secaron en estufa de aire forzado a $65{ }^{\circ} \mathrm{C}$ por $48 \mathrm{~h}$. El RMS por especie dentro de cada edad de rebrote se calculó en base a la concentración de MS obtenida de los $300 \mathrm{~g}$ de MV y al rendimiento
Bentham). These species were sown on August 8,2012 in plots of $2 \times 4 \mathrm{~m}$, at a seeding density of $5 \mathrm{~kg}$ seed ha-1 distributed in five furrows drawn along the length of each plot and spaced at $50 \mathrm{~cm}$, except cacahuatillo. This latter was seeded with vegetative material (root stems) at a distance of $25 \mathrm{~cm}$ from stem to stem. The plots were distributed at random in the field, spacing between them was $1.5 \mathrm{~m}$ and with three replicates per species.

Each plot was divided into four subplots of $2 x$ $1 \mathrm{~m}$, one of four regrowth ages: 21, 42, 63 and $84 \mathrm{~d}$ were assigned at random. The regrowth age in days were counted after cutting uniformly, which occurred for all plots on February 26 for the dry season, and May 20 for the rainy season. Thus, harvests in the dry season were carried out on March 18, April 8 and 29 and for the rainy season on May 20, on June 10, July 1 and 22 and August 12. In each subplot (regrowth age), all biomass or green matter (GM) with cuts of $10 \mathrm{~cm}$ from ground level for stylo, and $5 \mathrm{~cm}$ for the other legumes harvested. The collected material was weighed in a portable electronic scale with capacity of $10 \mathrm{~kg} \pm 1 \mathrm{~g}$. To determine the yield of dry matter (DMY $t$ ha-1 $^{-1}$ ), subsamples of $300 \mathrm{~g}$ of GM were separated, which were dried in forced air oven at $65^{\circ} \mathrm{C}$ for $48 \mathrm{~h}$. The DMY per species within each regrowth age was calculated based on the concentration of DM obtained from 300 $g$ of GM and GM yield total harvest of each subplot. The leaf-total aboveground biomass ratio was determined by taking leaves and stems of an additional subsample of $100 \mathrm{~g}$ of GM. These leaves and stems were separated and dried separately in stoves with forced air at $65^{\circ}$ $\mathrm{C}$ for $48 \mathrm{~h}$. After drying the leaf-total aboveground biomass ratio was obtained by dividing the dry weight of leaves by total dry weight of leaves + stems.

The protein concentrations $\left(\mathrm{g} \mathrm{kg}^{-1} \mathrm{DM}\right)$ and neutral detergent fiber (NDF, $\mathrm{g} \mathrm{kg}^{-1} \mathrm{DM}$ ) were quantified in the dry samples of GM $300 \mathrm{~g}$, which were previously ground to a particle size of $1 \mathrm{~mm}$. Protein concentration was determined 
de MV total cosechado de cada subparcela. Para la proporción de hojas en la biomasa aérea total ( $\left.\mathrm{g} \mathrm{kg}^{-1} \mathrm{MS}\right)$, se tomó una submuestra adicional de $100 \mathrm{~g}$ de MV, en la que se separaron hojas de tallos y ambos se secaron por separado en estufas de aire forzado a $65{ }^{\circ} \mathrm{C}$ por $48 \mathrm{~h}$. Posterior al secado se obtuvo la proporción de hojas en la biomasa aérea total, dividiendo el peso seco de hojas por el peso seco total de hojas + tallos.

Las concentraciones de proteína ( $\left.\mathrm{g} \mathrm{kg}^{-1} \mathrm{MS}\right)$ y de fibra detergente neutro (FDN, $\mathrm{g} \mathrm{kg}^{-1} \mathrm{MS}$ ) se cuantificaron en las muestras secas de $300 \mathrm{~g}$ de $\mathrm{MV}$, que fueron previamente molidas a un tamaño de partícula de $1 \mathrm{~mm}$. La concentración de proteína se determinó por el método Kjeldhal, multiplicando el porcentaje de nitrógeno x 6.25(10). La FDN, empleando sulfato lauril sódico a pH neutro, por la metodología de Van Soest(11).

La degradabilidad in situ de la MS ( $\mathrm{g} \mathrm{kg}^{-1} \mathrm{MS}$ ) se determinó a $48 \mathrm{~h}$ de incubación de acuerdo a la técnica de las bolsas de nylon(12), con las recomendaciones de Villalobos(13) y Ayala(14), con toros de cruzas Bos Taurus $x$ Bos indicus con fístula ruminal. Se emplearon cuatro toros y en cada toro se introducían las muestras por duplicado; es decir, 24 bolsitas por toro. La fórmula para el cálculo fue: degradabilidad in situ= ( $g$ MS inicial - g MS residual) / g MS inicial.

El análisis de varianza aplicado a todas la variables de respuesta fue en base al programa GLM del SAS(15). El efecto de especie, de edad de rebrote y de la interacción especie $\mathrm{x}$ edad de rebrote se analizó separadamente por época del año, siendo el diseño completamente al azar en arreglo de parcelas divididas; la parcela principal fue la especie y la parcela secundaria la edad de rebrote. Estos dos factores más sus interacciones fueron incluidos en el modelo. La comparación entre medias fue por el método de Tukey $(P<0.05)$ y las correlaciones entre las variables con el programa CORR, calculadas a partir de las medias de los datos obtenidos en campo, para cada combinación especie $\mathrm{x}$ edad de rebrote. by the Kjeldahl method, this involves multiplying the percentage of nitrogen $\times 6.25(10)$. NDF was determined using sodium lauryl sulfate at a neutral $\mathrm{pH}$ by the methodology of Van Soest(11).

The in situ DM ( $\left.\mathrm{g} \mathrm{kg}^{-1} \mathrm{DM}\right)$ degradability was determined at $48 \mathrm{~h}$ of incubation according to the technique of nylon bags(12) with the recommendations of Villalobos(13) and Ayala(14), using cross bred bulls Bos Taurus $x$ Bos indicus with ruminal fistula. Four bulls were used and for each bull the sample was introduced in duplicate; i.e. 24 bags per bull. The formula for the calculation of in situ degradability $=(\mathrm{g}$ initial DM - $g$ residual DM) / $g$ initial DM.

The variance analysis applied to all the variables of response was based on the SAS GLM program(15). The effect of species, age of regrowth and interaction species $x$ age of regrowth was analyzed separately by time of year, using a completely randomized design in split plot arrangement. The main plot was the species and the secondary plot regrowth age. These two factors plus their interactions were included in the model. Comparison of means was carried out by the method of Tukey $(P<0.05)$ and correlations between variables with the CORR program, calculated from the averages of the field data for each particular species $x$ age of regrowth.

\section{Environmental conditions}

The temperature and precipitation for the two periods evaluated for the year are presented in Figure 1 . In the dry season (March, April and May) the highest temperatures and lowest average rainfall was recorded compared to the rainy season. In March the lowest temperature was recorded, $3.7^{\circ} \mathrm{C}$ lower than the average of April and May. These last two months had $1{ }^{\circ} \mathrm{C}$ higher average temperature than the rainy season. There was a marked difference in rainfall between the two periods, $190 \mathrm{~mm}$ of rain was recorded in the dry season than in the rainy season. In May there were $98 \mathrm{~mm}$ more rainfall than the average for the months of March and April. 
Condiciones ambientales

La temperatura y precipitación pluvial para las dos épocas evaluadas del año, se presentan en la Figura 1. En la época seca (marzo, abril y mayo) se registró la mayor temperatura y menor precipitación promedio con respecto a la época de lluvias. En marzo se registró la menor temperatura, $3.7{ }^{\circ} \mathrm{C}$ menos con respecto al promedio de abril y mayo. Estos dos últimos meses tuvieron $1{ }^{\circ} \mathrm{C}$ más que la temperatura promedio de la época de lluvias. Fue marcada la diferencia en precipitación pluvial entre las dos épocas, registrándose 190 mm más de lluvia en la época lluviosa que en la época seca. En mayo hubo $98 \mathrm{~mm}$ más de lluvia que el promedio registrado de los meses marzo a abril.

Rendimiento de materia seca total (RMS) y proporción de hoja en la biomasa aérea total Hubo interacción especie $x$ edad de rebrote en ambas épocas del año para el RMS (Cuadro 1 ).
Total dry matter yield (DMY) and leaf-total aboveground biomass ratio

There was interaction species $x$ regrowth age in both seasons for the DMY (Table 1). In the dry season, stylo was the species that mostly contributed to this interaction by increasing its DMY 3.7 t ha-1, from 63 to $84 \mathrm{~d}$ of regrowth (Figure 2a). This significant increase changed the production status stylo with respect to other species, and coincided with the significant increase in rainfall in May. This result shows the high potential of stylo in response to favorable moisture conditions. Kudzu was the species had the lowest yields throughout the dry season, but at 21 and $84 \mathrm{~d}$ showed similar yields to that of clitoria, with average values of 0.39 and 3.56 t ha-1, $^{-1}$ respectively. In the rainy season the interaction species $x$ age of regrowth was caused by four species, which changed its production status by age of regrowth (Figure 2c) and stylo again recorded a high DMY at 84

Figura 2. Rendimiento de materia seca y proporción de hoja en la biomasa aérea total de cuatro leguminosas forrajeras en cuatro edades de rebrote durante la época seca (a, b) y lluviosa (c, d)

Figure 2. Yield of dry matter and Leaf total aboveground biomass ratio of four forage legumes into four stages of regrowth during the dry $(a, b)$ and rainy $(c, d)$ season
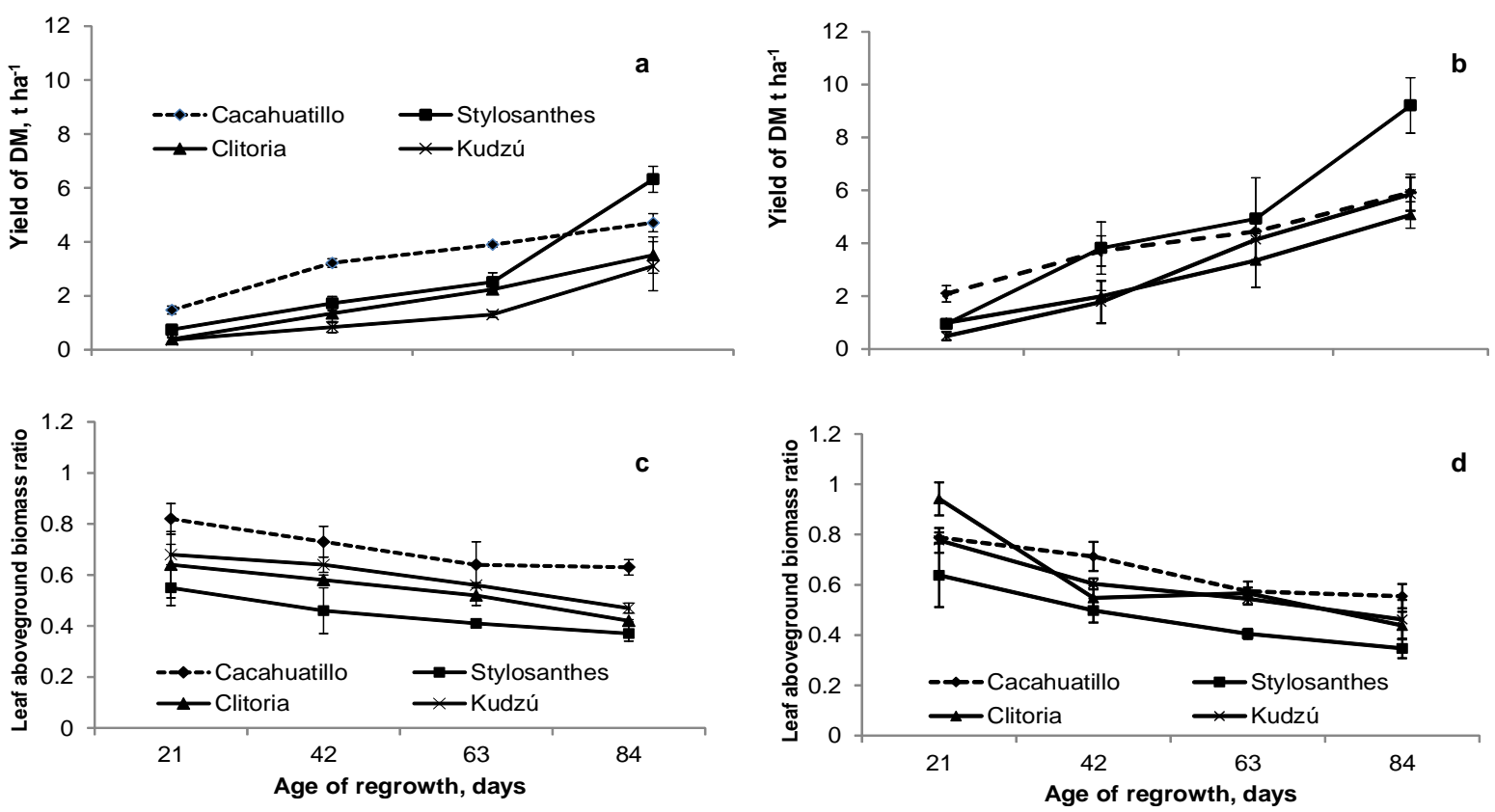
En la época seca, stylo fue la especie que mayormente contribuyó en dicha interacción al incrementar su RMS en 3.7 t ha-1, al pasar de los 63 a los 84 días de rebrote (Figura 2a). Este incremento significativo cambió el estado productivo de stylo con respecto al resto de las especies, y coincidió con el aumento importante en precipitación pluvial del mes de mayo. Este resultado muestra el alto potencial de respuesta de stylo a las condiciones favorables de humedad. Kudzú fue la especie que mantuvo los menores rendimientos durante toda la época seca, pero a los 21 y 84 días registró rendimientos semejantes a clitoria, con valores promedios de 0.39 y 3.56 t ha-1, respectivamente. En la época de lluvias la interacción especie $x$ edad de rebrote fue originada por las cuatro especies, las cuales cambiaron su status productivo según la edad de rebrote (Figura 2c), y en stylo se registró nuevamente un alto RMS a los 84 días de rebrote, lo cual coincidió con el registro del mes más lluvioso (agosto) dentro de esta época d regrowth, which coincided with the wettest month recorded (August) within the rainy season. At this time, again clitoria and kudzu are the species with smallest DMY throughout their growth period, with similar values as stylo at $21 \mathrm{~d}(0.865 \mathrm{t} \mathrm{ha-1}$, the average of the three species), and cacahuatillo at $84 \mathrm{~d}$ (5.61 t ha1 on average). In both seasons, the DMY had a progressive increase with age of regrowth, with an average variation of the four species, from 0.749 to $4.37 \mathrm{t} \mathrm{ha}^{-1}$ during the 21 to 84 $\mathrm{d}$ of regrowth in the dry season. In the rainy season this increase was 1.17 to $6.52 \mathrm{t} \mathrm{ha}^{-1}$ in the same time period of growth.

The interaction of species $x$ age of regrowth was present only in the rainy season for the leaf-to-stem ratio (LSR) (Table 1). In the dry season, the four species maintained their values in terms of LSR at different ages of regrowth (Figure 2b), where cacahuatillo and stylo species had the highest and lowest values of LSR at the different ages of regrowth, respectively. In

Cuadro 1. Cuadrados medios para rendimiento de materia seca total (DMY), proporción de hojas en la biomasa aérea (LTAB), proteína, degradabilidad y fibra detergente neutro (NDF) de cuatro leguminosas cosechadas a cuatros edades de rebrote en dos épocas del año

Table 1. Least square means for total dry matter yield (DMY), leaf-total above ground biomass ratio (LTAB), protein, degradability and neutral detergent fiber (NDF) for four legumes harvested at four ages of regrowth in two seasons

\begin{tabular}{|c|c|c|c|}
\hline Variable measured & Species ( S ) & Age of regrowth ( $A$ ) & $S \times A$ \\
\hline \multicolumn{4}{|l|}{ Dry season: } \\
\hline DMY, t ha-1 & 9.48 ** & $28.04 * * *$ & $1.522 * * *$ \\
\hline LTAB & $141134.7^{\star *}$ & $86612.9^{* * *}$ & 1484.0 \\
\hline Protein, $\mathrm{g} \mathrm{kg}^{-1} \mathrm{DM}$ & 8853.2 ** & $11633.2^{* * *}$ & $748.6^{* * *}$ \\
\hline Degradability, $\mathrm{g} \mathrm{kg}^{-1} \mathrm{DM}$ & $98850.6^{* * *}$ & $71995.1^{* * *}$ & $6534.0 * * *$ \\
\hline NDF, $\mathrm{g} \mathrm{kg}^{-1} \mathrm{DM}$ & $56240.3^{* * *}$ & $50564.5^{* * *}$ & $100.5^{* * *}$ \\
\hline \multicolumn{4}{|l|}{ Rainy season: } \\
\hline DMY, t ha-1 & $8.94^{* * *}$ & $61.50 * * *$ & 2.41 ** \\
\hline LTAB & $78030.8^{* * *}$ & $250800.9 * * *$ & 11367.1 ** \\
\hline Protein, $\mathrm{g} \mathrm{kg}^{-1} \mathrm{DM}$ & $8052.9 * *$ & $7001.9^{* * *}$ & $1638.0 * * *$ \\
\hline Degradability, $\mathrm{g} \mathrm{kg}^{-1} \mathrm{DM}$ & $84345.9^{* * *}$ & $98726.9^{* * *}$ & $6263.2 * * *$ \\
\hline NDF, $g_{k g}^{-1}$ DM & $20901.1^{* *}$ & $44491.24^{* * *}$ & 3352.2 ** \\
\hline DF & 3 & 3 & 9 \\
\hline
\end{tabular}

**, $* * *$ Significance at a probability level of 0.01 and 0.001 , respectively. DF $=$ degrees of freedom. 
de Iluvias. En esta época, nuevamente clitoria y kudzú son las especies con los menores RMS a lo largo de su crecimiento, con valores semejantes a stylo a los 21 días (0.865 t ha1 , promedio de las tres especies), y a cacahuatillo a los 84 días (5.61 t ha-1 en promedio). En ambas épocas del año, el RMS tuvo un incremento progresivo con la edad de rebrote, con una variación promedio de las cuatro especies, de 0.749 a $4.37 \mathrm{t} \mathrm{ha}^{-1}$ al pasar de los 21 a los 84 días en la época seca. En la época de lluvias este incremento fue de 1.17 a $6.52 \mathrm{t} \mathrm{ha-1}$ en el mismo período de crecimiento.

La interacción especie $x$ edad de rebrote estuvo presente sólo en la época de lluvias para la proporción de hojas (Cuadro 1). En la época seca, las cuatro especies mantuvieron su status en proporción de hoja en las diferentes edades the rainy season interaction was induced by clitoria, it changed from being a species with high LSR at $21 \mathrm{~d}$ of regrowth, to become a species with lower LSR (along with stylo) at $42 \mathrm{~d}$, to later increase its LSR with advancing age of regrowth (Figure $2 \mathrm{~d}$ ). Cacahuatillo and stylo species also had higher and lower LSR, respectively, at different ages of regrowth at this time (except in rainy season at $21 \mathrm{~d}$ ). In both seasons, a decreasing pattern in the values of leaf-total aboveground biomass ratio with advancing age of regrowth was recorded, being more accentuated in all species during the rainy season (Table 2). However, between regrowth ages, after $42 \mathrm{~d}$ no differences of regrowth was found for this parameter in all four legumes evaluated in both seasons. In the dry season, the average value of leaf-total aboveground biomass ratio species decreased from 0.676 to 0.480 at 21 to $84 \mathrm{~d}$ of regrowth ages, and

Cuadro 2. Biomasa aérea total, proporción de hoja y valor nutritivo de cuatro leguminosas forrajeras en cuatro edades de rebrote durante dos épocas del año

Table 2. Total aboveground biomass, leaf ratio and nutritive value of four forage legumes at four stages of regrowth during two seasons of the year

\begin{tabular}{|c|c|c|c|c|c|c|c|c|c|c|c|}
\hline & \multirow{2}{*}{$\begin{array}{l}\text { Age of } \\
\text { regrowth } \\
\text { (days) }\end{array}$} & \multicolumn{2}{|c|}{$\begin{array}{c}\text { Total above } \\
\text { ground biomass, } \\
\text { t ha-1 DM } \\
\end{array}$} & \multicolumn{2}{|c|}{$\begin{array}{l}\text { Leaf-total } \\
\text { aboveground } \\
\text { biomass ratio }\end{array}$} & \multicolumn{2}{|c|}{$\begin{array}{c}\text { Protein, } \\
\left(\mathrm{g} \mathrm{kg}^{-1} \mathrm{DM}\right) \\
\end{array}$} & \multicolumn{2}{|c|}{$\begin{array}{r}\text { Degradability } \\
\left(\mathrm{g} \mathrm{kg}^{-1} \mathrm{DM}\right)\end{array}$} & \multicolumn{2}{|c|}{$\begin{array}{c}\text { Neutral detergent } \\
\text { fiber, } \\
\left(\mathrm{g} \mathrm{kg}^{-1} \mathrm{DM}\right)\end{array}$} \\
\hline & & $\begin{array}{c}\text { Dry } \\
\text { season }\end{array}$ & $\begin{array}{l}\text { Rainy } \\
\text { season }\end{array}$ & $\begin{array}{c}\text { Dry } \\
\text { season }\end{array}$ & $\begin{array}{l}\text { Rainy } \\
\text { season }\end{array}$ & $\begin{array}{c}\text { Dry } \\
\text { season }\end{array}$ & $\begin{array}{l}\text { Rainy } \\
\text { season }\end{array}$ & $\begin{array}{c}\text { Dry } \\
\text { season }\end{array}$ & $\begin{array}{l}\text { Rainy } \\
\text { season }\end{array}$ & $\begin{array}{c}\text { Dry } \\
\text { season }\end{array}$ & $\begin{array}{l}\text { Rainy } \\
\text { season }\end{array}$ \\
\hline acahuatillo & $\begin{array}{l}21 \\
42 \\
63 \\
84\end{array}$ & $\begin{array}{l}1.47 \mathrm{~d} \\
3.22 \mathrm{c} \\
3.90 \mathrm{~b} \\
4.71 \mathrm{a}\end{array}$ & $\begin{array}{l}2.09 \mathrm{c} \\
3.71 \mathrm{~b} \\
4.45 \mathrm{~b} \\
5.92 \mathrm{a}\end{array}$ & $\begin{array}{l}0.822 a \\
0.736 a b \\
0.648 b \\
0.639 b\end{array}$ & $\begin{array}{l}0.788 \mathrm{a} \\
0.713 \mathrm{a} \\
0.574 \mathrm{~b} \\
0.555 \mathrm{~b}\end{array}$ & $\begin{array}{l}185.9 \mathrm{a} \\
165.7 \mathrm{~b} \\
162.1 \mathrm{~b} \\
150.8 \mathrm{~b}\end{array}$ & $\begin{array}{l}218.4 \mathrm{a} \\
176.9 \mathrm{~b} \\
157.7 \mathrm{~b} \\
119.0 \mathrm{c}\end{array}$ & $\begin{array}{l}801.9 \mathrm{a} \\
789.8 \mathrm{a} \\
778.3 \mathrm{ab} \\
744.8 \mathrm{~b}\end{array}$ & $\begin{array}{l}775.9 \mathrm{a} \\
761.0 \mathrm{ab} \\
749.7 \mathrm{~b} \\
716.9 \mathrm{c}\end{array}$ & $\begin{array}{l}593.9 \mathrm{~b} \\
608.0 \mathrm{~b} \\
620.5 \mathrm{ab} \\
672.4 \mathrm{a}\end{array}$ & $\begin{array}{l}548.1 \mathrm{c} \\
591.9 \mathrm{bc} \\
618.0 \mathrm{ab} \\
644.6 \mathrm{a}\end{array}$ \\
\hline Stylo & $\begin{array}{l}21 \\
42 \\
63 \\
84\end{array}$ & $\begin{array}{l}0.75 \mathrm{~b} \\
1.72 \mathrm{~b} \\
2.51 \mathrm{~b} \\
6.30 \mathrm{a}\end{array}$ & $\begin{array}{l}0.94 \mathrm{c} \\
3.82 \mathrm{~b} \\
4.93 \mathrm{~b} \\
9.21 \mathrm{a}\end{array}$ & $\begin{array}{l}0.554 a \\
0.461 a b \\
0.410 a b \\
0.379 b\end{array}$ & $\begin{array}{l}0.638 \mathrm{a} \\
0.498 \mathrm{ab} \\
0.405 \mathrm{~b} \\
0.347 \mathrm{~b}\end{array}$ & $\begin{array}{l}183.1 \mathrm{a} \\
133.2 \mathrm{~b} \\
117.3 \mathrm{c} \\
111.2 \mathrm{c}\end{array}$ & $\begin{array}{l}145.4 \mathrm{a} \\
137.8 \mathrm{ab} \\
126.3 \mathrm{~b} \\
124.0 \mathrm{~b}\end{array}$ & $\begin{array}{l}739.6 \mathrm{a} \\
636.9 \mathrm{~b} \\
628.9 \mathrm{~b} \\
538.5 \mathrm{c}\end{array}$ & $\begin{array}{l}720.1 \mathrm{a} \\
669.0 \mathrm{~b} \\
563.2 \mathrm{c} \\
547.7 \mathrm{c}\end{array}$ & $\begin{array}{l}704.7 \mathrm{a} \\
720.9 \mathrm{a} \\
730.1 \mathrm{a} \\
741.3 \mathrm{a}\end{array}$ & $\begin{array}{l}570.7 \mathrm{~b} \\
590.4 \mathrm{~b} \\
673.3 \mathrm{a} \\
714.1 \mathrm{a}\end{array}$ \\
\hline Clitoria & $\begin{array}{l}21 \\
42 \\
63 \\
84\end{array}$ & $\begin{array}{l}0.39 \mathrm{c} \\
1.35 \mathrm{bc} \\
2.24 \mathrm{~b} \\
3.85 \mathrm{a}\end{array}$ & $\begin{array}{l}0.99 \mathrm{c} \\
1.99 \mathrm{bc} \\
3.35 \mathrm{~b} \\
5.07 \mathrm{a}\end{array}$ & $\begin{array}{l}0.641 a \\
0.586 a b \\
0.522 a b \\
0.425 b\end{array}$ & $\begin{array}{l}0.942 a \\
0.561 \mathrm{~b} \\
0.548 \mathrm{~b} \\
0.438 \mathrm{~b}\end{array}$ & $\begin{array}{l}211.3 \mathrm{a} \\
188.1 \mathrm{ab} \\
173.3 \mathrm{~b} \\
141.5 \mathrm{c}\end{array}$ & $\begin{array}{l}182.8 \mathrm{a} \\
166.0 \mathrm{ab} \\
164.6 \mathrm{~b} \\
163.8 \mathrm{~b}\end{array}$ & $\begin{array}{l}760.0 \text { a } \\
635.5 \mathrm{~b} \\
604.6 \mathrm{~b} \\
603.0 \mathrm{~b}\end{array}$ & $\begin{array}{l}693.4 \mathrm{a} \\
666.2 \mathrm{a} \\
627.7 \mathrm{~b} \\
517.5 \mathrm{c}\end{array}$ & $\begin{array}{l}473.2 \mathrm{c} \\
634.7 \mathrm{~b} \\
668.3 \mathrm{ab} \\
704.8 \mathrm{a}\end{array}$ & $\begin{array}{l}570.1 \mathrm{~b} \\
604.8 \mathrm{~b} \\
654.8 \mathrm{a} \\
684.4 \mathrm{a}\end{array}$ \\
\hline Kudzú & $\begin{array}{l}21 \\
42 \\
63 \\
84 \\
\end{array}$ & $\begin{array}{l}0.37 \mathrm{~b} \\
0.84 \mathrm{~b} \\
1.31 \mathrm{~b} \\
3.28 \mathrm{a} \\
\end{array}$ & $\begin{array}{l}0.64 \mathrm{c} \\
1.78 \mathrm{c} \\
4.14 \mathrm{~b} \\
5.86 \mathrm{a} \\
\end{array}$ & $\begin{array}{l}0.686 a \\
0.648 a b \\
0.568 b \\
0.477 c \\
\end{array}$ & $\begin{array}{l}0.777 \mathrm{a} \\
0.604 \mathrm{~b} \\
0.544 \mathrm{bc} \\
0.462 \mathrm{c}\end{array}$ & $\begin{array}{l}163.6 \mathrm{a} \\
147.0 \mathrm{~b} \\
141.0 \mathrm{~b} \\
131.7 \mathrm{~b}\end{array}$ & $\begin{array}{l}151.8 \mathrm{a} \\
147.7 \mathrm{a} \\
136.1 \mathrm{~b} \\
130.8 \mathrm{~b}\end{array}$ & $\begin{array}{l}728.3 \mathrm{a} \\
699.2 \mathrm{a} \\
682.8 \mathrm{a} \\
613.5 \mathrm{~b} \\
\end{array}$ & $\begin{array}{l}737.2 \mathrm{a} \\
704.4 \mathrm{a} \\
620.2 \mathrm{~b} \\
566.9 \mathrm{c} \\
\end{array}$ & $\begin{array}{l}588.0 \mathrm{~b} \\
664.1 \mathrm{a} \\
669.0 \mathrm{a} \\
671.4 \mathrm{a} \\
\end{array}$ & $\begin{array}{l}658.4 \mathrm{~b} \\
664.6 \mathrm{~b} \\
675.6 \mathrm{ab} \\
690.2 \mathrm{a} \\
\end{array}$ \\
\hline
\end{tabular}

abc Means in the same column and within each section followed by different letters are significantly different $(P<0.05)$. 
de rebrote (Figura $2 \mathrm{~b}$ ), siendo cacahuatillo y stylo las especies con mayor y menor proporción de hoja en las diferentes edades de rebrote, respectivamente. La interacción presente en la época de lluvias, fue inducida por clitoria, al cambiar su estado de especie de mayor proporción de hoja a los 21 días de rebrote, a especie de menor proporción (junto con stylo) a los 42 días, para posteriormente remontar nuevamente su proporción de hoja con el avance de la edad de rebrote (Figura 2d). Cacahuatillo y stylo fueron también las especies de mayor y menor proporción de hojas, respectivamente, en las diferentes edades de rebrote en esta época (excepto en lluvias a los 21 días). En ambas épocas, se registró un patrón decreciente en la proporción de hoja con el avance de la edad de rebrote, siendo más acentuado en todas las especies en la época lluviosa (Cuadro 2).
0.786 to 0.450 during the rainy season in the same period of growth.

\section{Protein}

In both seasons there was interaction between species $x$ age of regrowth (Table 1 ), induced by the four species in the dry season, in terms of protein in each regrowth age (Figure 3a). In the rainy season, the interaction was given by cacahuatillo to become the species with the greatest concentration of protein at $21 \mathrm{~d}$, the species with lowest concentration was stylo and kudzu (124.3 $\mathrm{g} \mathrm{kg}^{-1}$ DM average for the three species) at $84 \mathrm{~d}$ (Figure 3d). During both seasons the protein concentration, the average of the four species, decreased with age of regrowth and ranged from 186 to $133.8 \mathrm{~g} \mathrm{~kg}^{-1}$ $\mathrm{DM}$ at $21-84 \mathrm{~d}$ in the dry season, and 174.64

Figura 3. Concentración de proteína, degradabilidad, fibra detergente neutro (NDF) de cuatro leguminosas forrajeras en cuatro edades de rebrote durante la época seca $(a, b, c)$ y de lluvias (d, e, f)

Figure 3. Concentration of protein, degradability, neutral detergent fiber (NDF) of four forage legumes into four ages of regrowth during the dry $(a, b, c)$ and rainy $(d, e, f)$ season
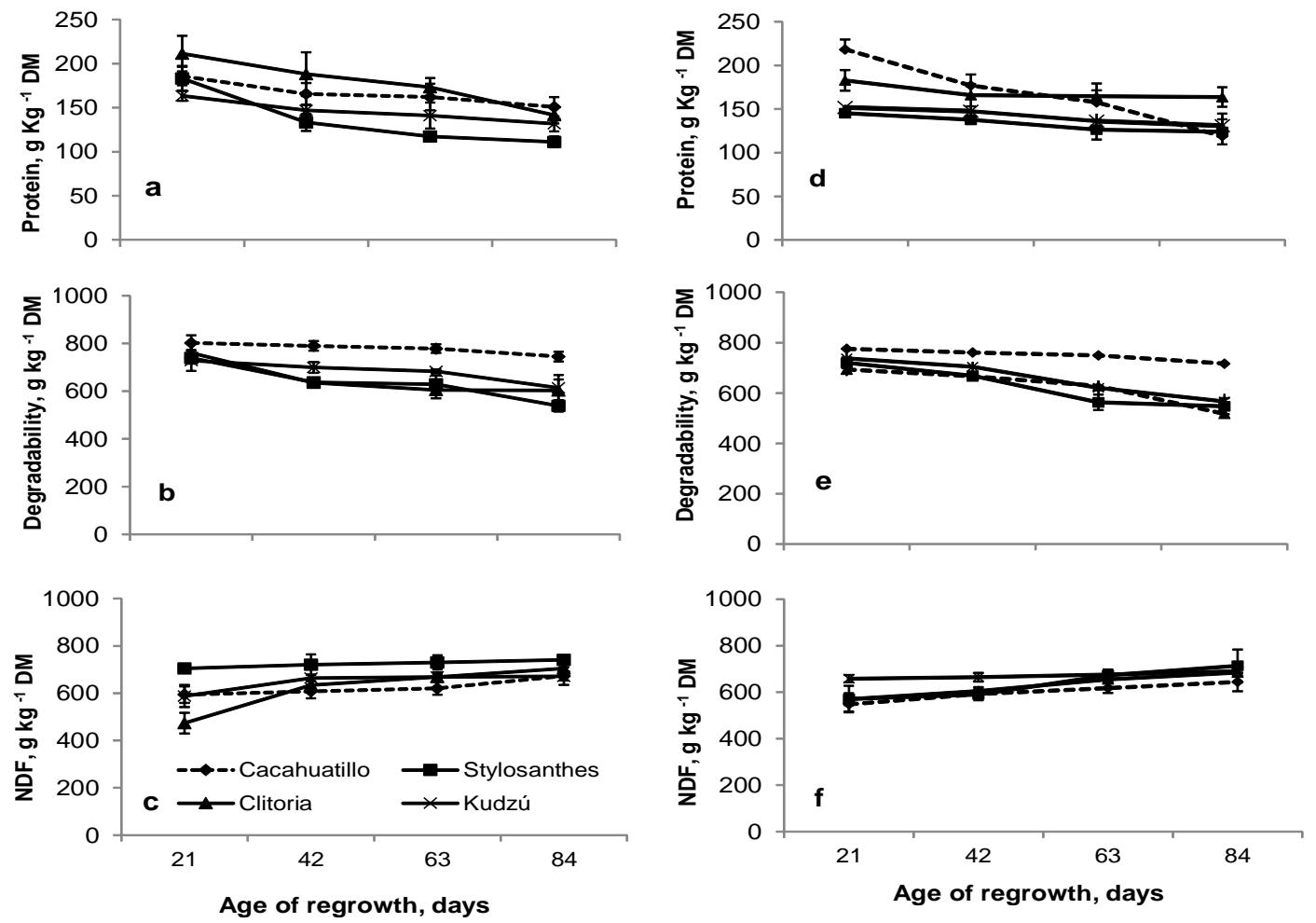
Sin embargo, entre edades de rebrote, no se observaron diferencias a partir de los 42 días de edad para este carácter en las cuatro leguminosas evaluadas en las dos épocas. En la época seca, la proporción de hoja promedio de las especies disminuyó de 0.676 a 0.480 $\mathrm{g} \mathrm{kg}^{-1}$ al pasar de los 21 a los 84 días de edad de rebrote, y de 0.786 a $0.450 \mathrm{~g} \mathrm{~kg}^{-1}$ de MS en la época de lluvias en el mismo período de crecimiento.

\section{Proteína}

En ambas épocas del año hubo interacción especie $x$ edad de rebrote (Cuadro 1), inducida por las cuatro especies en la época seca, al entrecruzarse sus registros de proteína en cada edad de rebrote (Figura 3a). En la época de lluvias, la interacción es dada por cacahuatillo al cambiar de especie de mayor concentración de proteína a los 21 días, a la especie de menor concentración junto con stylo y kudzú (124.3 g $\mathrm{kg}^{-1}$ de MS promedio de las tres especies) a los 84 días (Figura 3d). En ambas épocas la concentración de proteína, promedio de las cuatro especies, disminuye con la edad de rebrote variando de 186 a $133.8 \mathrm{~g} \mathrm{~kg}^{-1}$ de MS, al pasar de 21 a 84 días en la época seca, y de 174.64 a $134.44 \mathrm{~g} \mathrm{~kg}^{-1} \mathrm{MS}$, en la época de lluvias en el mismo período. No obstante, la to $134.44 \mathrm{~g} \mathrm{~kg}^{-1} \mathrm{DM}$ in the rainy season during the same period. However, the protein concentration showed its greatest decline after an age of $42 \mathrm{~d}$, in most species tested. In both seasons of the year clitoria and cacahuatillo maintain the highest concentration of protein with regrowth age, also evident was that cacahuatillo and kudzu did not alter their protein concentration after $42 \mathrm{~d}$ of regrowth in the dry season (Table 2). The latter two species also maintained stability in terms of leaf-total aboveground biomass ratio in the dry season, which could influence the close relationship that exists between protein concentration and leaftotal aboveground biomass ratio (Table 3). Stylo, however, was the species that recorded the lowest concentrations of protein (which coincides with the lowest values of leaf-total aboveground biomass ratio) at different ages of regrowth in both seasons (except at $21 \mathrm{~d}$ in the dry season). In this legume, protein concentrations were observed in the rainy season greater than levels observed in the dry season from $42 \mathrm{~d}$ of age.

\section{Degradability}

The interaction species $x$ regrowth age in both seasons was produced by the change of regrowth age in the stylo, clitoria and kudzu species (Figures $3 \mathrm{~b}$ and $\mathrm{c}$ ). In both seasons,

Cuadro 3. Correlaciones entre los diferentes caracteres evaluados en la época seca y de lluvias (en negritas)

Table 3. Correlations between different variables evaluated in the dry and rainy seasons (in bold)

\begin{tabular}{|c|c|c|c|c|}
\hline Trait & LTAB & Protein & Degradability & $\begin{array}{c}\text { Neutral detergent } \\
\text { fiber }\end{array}$ \\
\hline Total aboveground biomass & $\begin{array}{c}-0.383 \\
-0.770^{* * *}\end{array}$ & $\begin{array}{l}-0.568 * \\
-0.549 *\end{array}$ & $\begin{array}{c}-0.352 \\
-0.613\end{array}$ & $\begin{aligned} & 0.460 \\
- & 0.642\end{aligned}$ ** \\
\hline LTAB & & $\begin{array}{l}0.665^{* *} \\
\mathbf{0 . 6 8 6}\end{array}$ & $\begin{array}{l}0.890^{* * *} \\
\mathbf{0 . 7 4 4}\end{array}$ & $\begin{array}{l}-0.719^{* *} \\
-0.698^{* *}\end{array}$ \\
\hline Protein & & & $\begin{array}{c}0.619 * \\
0.481\end{array}$ & $\begin{array}{l}-0.785^{* * *} \\
-0.665^{* *}\end{array}$ \\
\hline Digestibility & & & & $\begin{array}{l}-0.659^{\star *} \\
-\mathbf{0 . 7 4 4}\end{array}$ \\
\hline
\end{tabular}

$\mathrm{LTAB}=$ Leaf-total above ground biomass ratio.

${ }^{*},{ }^{* *},{ }^{* *}$ Significance probability levels of $0.05,0.01$ and 0.001 respectively. 
concentración de proteína muestra su mayor disminución después de los 42 días de edad, en la mayoría de las especies evaluadas. En ambas épocas de año cacahuatillo y clitoria mantienen la mayor concentración de proteína con la edad de rebrote, observándose también que cacahuatillo y kudzú no variaron su concentración de proteína a partir de los 42 días de rebrote en la época seca (Cuadro 2). Estas dos últimas especies también mantuvieron estabilidad en la proporción de hoja en la época seca, lo que pudo influir en la relación estrecha que existió entre la concentración de proteína y proporción de hoja (Cuadro 3). Stylo, por el contrario, fue la especie que registró las menores concentraciones de proteína (lo cual coincide con su menor proporción de hoja) en las diferentes edades de rebrote en ambas épocas (excepto a los 21 días en la época seca). En esta leguminosa, se observan concentraciones de proteína en la época de lluvias superiores a las registradas en la época seca a partir de los 42 días de edad.

\section{Degradabilidad}

La interacción especie $x$ edad de rebrote en ambas épocas del año, estuvo originada por el cambio de edad de rebrote, de las especies stylo, clitoria y kudzú (Figuras 3b y e). En ambas épocas, la degradabilidad de la MS mantuvo un patrón decreciente con la edad. En la época seca, disminuyó de 757.48 a $624.99 \mathrm{~g} \mathrm{~kg}^{-1}$ de MS al pasar de los 21 a los 84 días de rebrote, respectivamente y en la época de lluvias, de 731.72 a $587.29 \mathrm{~g} \mathrm{~kg}^{-1}$ de MS, en el mismo período. En ambas épocas, cacahuatillo registró los valores más altos de degradabilidad en las diferentes edades de rebrote (con valores por arriba de los $700 \mathrm{~g} \mathrm{~kg}^{-1}$ de MS en las diferentes edades) y mostró mayor estabilidad al disminuir su degradabilidad en sólo $57 \mathrm{~g} \mathrm{~kg}^{-1}$ de MS de los 21 a los 84 días de rebrote en la época seca, y en $59 \mathrm{~g} \mathrm{~kg}^{-1}$ de MS en lluvias en el mismo período (Cuadro 2). Lo anterior, está relacionado con la mayor proporción de hojas que también presentó cacahuatillo en ambas épocas, dado que éstas presentan menor the degradability of DM maintained a decreasing pattern with age. In the dry season decreasing from 757.48 to $624.99 \mathrm{~g} \mathrm{~kg}^{-1} \mathrm{DM}$, during the 21 to $84 \mathrm{~d}$ of regrowth, respectively, and in the rainy season, from 731.72 to $587.29 \mathrm{~g}$, in the same period. In both seasons, cacahuatillo recorded the highest degradability values at different ages of regrowth (with values above $700 \mathrm{~g}$ at different ages), and showed greater stability by decreasing its degradability to just $57 \mathrm{~g}$ at 21 to $84 \mathrm{~d}$ of regrowth in the dry season, and $59 \mathrm{~g}$ in the rainy season over the same regrowth period. The previous result (Table 2) is related to the higher leaf-total aboveground biomass ratio present in cacahuatillo during both seasons, since it has lower fiber concentration, and consequently the reason for its greater degradability, variations in degradability were highly related to variations in the values of leaf-total aboveground biomass ratio (Table 3). The remaining species (stylo, clitoria and kudzu) degradability values were below $650 \mathrm{~g} \mathrm{~kg}^{-1}$ DM after regrowth age of $42 \mathrm{~d}$ in both seasons.

Neutral detergent fiber

There was interaction of species $x$ age of regrowth for NDF given by the change of status in the dry season cacahuatillo, clitoria and kudzu, with advancing age of regrowth, and when the four species grew in the rainy season (Figures $3 \mathrm{c}$ and $\mathrm{f}$ ). In both seasons a slight increase in the NDF with plant age, except stylo in the dry season (Table 2) was recorded. In this period, stylo maintained the highest values in each of the regrowth ages, with an average concentration of $724 \mathrm{~g} \mathrm{~kg}^{-1}$ DM. The average of the four species showed that NDF increased from 590 to $687.51 \mathrm{~g}$ from 21 to $84 \mathrm{~d}$ of regrowth in the dry season, and 586.87 to $683.38 \mathrm{~g}$ in the rainy season in the same period. Cacahuatillo was the species that recorded the lowest values in all regrowth ages except at $21 \mathrm{~d}$ in the dry season. In general, the concentration of NDF was inversely related to the leaf-total aboveground biomass ratio, the 
concentración de fibra, y en consecuencia mayor degradabilidad, razón por la cual, las variaciones en degradabilidad estuvieron altamente relacionadas con las variaciones en proporción de hoja (Cuadro 3). El resto de las especies (stylo, clitoria y kudzú) presentaron valores de degradabilidad por debajo de los $650 \mathrm{~g} \mathrm{~kg}^{-1}$ de MS a partir de los 42 días de edad de rebrote en ambas épocas del año.

Fibra detergente neutro

Hubo interacción especie $x$ edad de rebrote para FDN dada por el cambio de status en la época seca de cacahuatillo, clitoria y kudzú, al avanzar la edad de rebrote, y de las cuatro especies en lluvias (Figuras $3 c$ y f). En ambas épocas se registró un ligero incremento de la FDN con la edad de la planta, a excepción de stylo en la época seca (Cuadro 2). En esta época, stylo mantuvo los valores más altos en cada una de las edades de rebrote, con una concentración promedio de $724 \mathrm{~g} \mathrm{~kg}^{-1}$ de MS. Como promedio de las cuatro especies, la FDN aumentó de 590 a $687.51 \mathrm{~g} \mathrm{~kg}^{-1}$ de MS de los 21 a los 84 días de rebrote en la época seca, y de 586.87 a $683.38 \mathrm{~g}$ en la época de lluvias en el mismo período. Cacahuatillo fue la especie que registró los valores más bajos en todas las edades de rebrote, excepto a los 21 días en la época seca del año. En general, la concentración de FDN estuvo inversamente relacionada con la proporción de hojas, la concentración de proteína y la degradabilidad de la materia seca (Cuadro 3).

La interacción especie $x$ edad de rebrote estuvo presente para todos los caracteres evaluados, lo que muestra la respuesta diferencial en crecimiento de las especies evaluadas al ambiente(16), principalmente a la humedad del suelo, y posiblemente al fotoperíodo(17), lo que les hace más difícil mantener una estabilidad de respuesta a las diferentes condiciones ambientales que se suscitan a lo largo del periodo de crecimiento. Además la intensidad y calidad de luz, así como el estrés hídrico inciden en la composición química de la planta $(18,19)$ y protein concentration and the degradability of dry matter (Table 3).

The interaction species $x$ age of regrowth was present for all traits evaluated, which show that tested species have a differential response to the environment for growth(16), mainly soil moisture, and possibly photoperiod(17), which makes it more difficult to maintain a stable response to different environmental conditions that arise during the growth period. Also the intensity and quality of light and water stress can affect the chemical composition of the plant $(18,19)$ and the response can vary between legumes(20). This is mainly reflected in the differences in DMY of species between in the seasons evaluated, which has implications for the availability of forage between species per season for livestock. Furthermore, the maturity of the plant influences the availability and quality of feed(19). The DMY and NDF increased with age of regrowth in all species and the LSR, protein and digestibility decreased, and more acutely after $42 \mathrm{~d}$. Cacahuatillo and stylo always showed divergent responses in all traits evaluated, possibly a product of their contrasting growth habits: prostrate and erect, respectively.

The highest DMY in species were obtained at $84 \mathrm{~d}$, which is consistent with other studies in northern Veracruz(21), being stylo and cacahuatillo the species that excelled. In the dry season, cacahuatillo had yields above $3 \mathrm{t}$ ha-1 after $42 \mathrm{~d}$ of regrowth, although the literature presented it as a species with little tolerance to drought(22). In fact this response was expected of stylo based on reports of its tolerance to drought(23). This result is possibly due to the fact that during the months of the dry period there was light rain reaching values of $50 \mathrm{~mm}$ per month, with the month of May being exceptional with about $150 \mathrm{~mm}$, which favored the growth of cacahuatillo since water availability influences cell division, elongation and differentiation of leaf organs(20). By contrast, stylo recorded a high potential response to favorable moisture conditions, this species having the largest DMY during the rainy 
la respuesta puede variar entre leguminosas forrajeras(20). Esto se reflejó principalmente en las diferencias en RMS de las especies entre las épocas evaluadas, lo que tiene implicaciones en la disponibilidad del forraje entre especies por época del año para el ganado. Por otro lado, la madurez de la planta influye en la disponibilidad y calidad del forraje(19). El RMS y la FDN se incrementaron con la edad de rebrote en todas las especies y la proporción de hojas, proteína y digestibilidad disminuyeron, y de manera más acentuada después de los 42 días. Cacahuatillo y stylo siempre mostraron respuestas divergentes en todos los caracteres evaluados, producto posible de sus contrastantes hábitos de crecimiento: postrado y erecto, respectivamente.

Los mayores RMS en las especies se obtuvieron a los 84 días, lo que coincide con otros estudios realizados al norte de Veracruz(21), siendo cacahuatillo y stylo los que sobresalieron. En la época seca, cacahuatillo mostró rendimientos por arriba de las $3 \mathrm{t}$ ha-1 a partir de los 42 días de rebrote, a pesar que en la literatura se le presenta como especie poco tolerante a sequía(22). De hecho esta respuesta se esperaba de stylo en base a reportes de su tolerancia a sequía(23). Esto posiblemente se debió a que en los meses del período seco hubo lluvias ligeras cercanas a los $50 \mathrm{~mm}$ por mes, siendo el mes de mayo excepcional con cerca de 150 $\mathrm{mm}$, lo que favoreció el crecimiento de cacahuatillo, ya que la disponibilidad de agua influye en la división celular, elongación y diferenciación de órganos foliares(20). Por el contrario, stylo registró un alto potencial de respuesta a las condiciones favorables de humedad, siendo esta especie la de mayor RMS en la época lluviosa en las diferentes edades de rebrote, y superó a cacachuatillo en el mes más húmedo de la época seca (mes de mayo), en $1.6 \mathrm{t} \mathrm{ha-1}$. Existe información disponible en la literatura(8) que apoya esta alta capacidad de respuesta de stylo a las condiciones favorables de humedad al compararse con otras leguminosas. season in the different regrowth ages and surpassed cacachuatillo in the wettest month of the dry season (May), with $1.6 \mathrm{t}$ ha- 1 . Information is available in the literature(8) that supports this high responsiveness of stylo to favorable moisture conditions compared with other legumes.

The variations in the LSR in total aboveground biomass, was a key factor in the variations of nutritive value, particularly protein, since a large proportion of $\mathrm{N}$ in the above ground vegetative material is derived from the reserves of $\mathrm{N}$ that are mobilized at the base of the stems or roots to the stems and leaves in development $(24,25)$. In addition, moisture promotes soil $\mathrm{N}$ mineralization and availability(26). Therefore, cacahuatillo species with the highest values of leaf-to-stem ratio at different ages of regrowth, it also had the highest concentration of protein degradability and the lowest NDF, in most ages of regrowth of the two seasons studied. These significant concentrations of protein and degradability of cacahuatillo are similar to those found in the same species in studies in South America(27). By contrast, stylo is a plant that is erect or semi-erect with a semi-woody main stem, which serves to as support, and has short branches, presented the lowest LSR and protein concentration in both seasons, and the highest concentration of NDF in the last two cutting ages during the rainy season. This lower protein concentration in stylo has been attributed to its high proportion of stems $(8,23)$, which increases the concentration of NDF.

Kudzu was the species with the lowest adaptation to the dry season, with DMY below 1 t ha-1 up to $42-d$ old, with a better response in the month of May (84-d old), due to increased storm precipitation. Although there are reports of high adaptation of this species due to drought(23), this adaptation is detrimental to their forage production. Although this species showed a leaf ratio close to that of cacahuatillo (above $600 \mathrm{~g} \mathrm{~kg}^{-1} \mathrm{DM}$ up to $42 \mathrm{~d}$, and about $500 \mathrm{~g} \mathrm{~kg}^{-1}$ DM from $63 \mathrm{~d}$ in both times), was overtaken by clitoria in protein concentration in 
Las variaciones en la proporción de hojas en la biomasa aérea total, fue un factor clave en las variaciones del valor nutritivo, en particular en proteína, dado que una gran proporción del $\mathrm{N}$ en las partes aéreas es derivado de las reservas de $\mathrm{N}$ que son movilizadas de las bases de los tallos o raíces a los tallos y hojas en desarrollo $(24,25)$, además de que la humedad favorece la mineralización del $\mathrm{N}$ del suelo y su disponibilidad(26). Por ello, cacahuatillo especie con las mayores proporciones de hojas en las diferentes edades de rebrote, fue también la de mayor concentración de proteína, degradabilidad, y de menor concentración de FDN, en la mayoría de las edades de rebrote de las dos épocas estudiadas. Estas importantes concentraciones de proteína y de degradabilidad en cacachuatillo son semejantes a las encontradas en esta misma especie en estudios realizados en Sud-América(27). Por el contrario, stylo es una planta de crecimiento erecto o semi-erecto con un tallo principal semi-leñoso, que le sirve de sostén, y de ramificaciones cortas, presentó la menor proporción de hojas en la biomasa aérea total y concentración de proteína en ambas épocas del año, y la mayor concentración de FDN en las dos últimas edades de corte en lluvias. Esta menor concentración de proteína en stylo se le ha atribuido a su gran proporción de tallos $(8,23)$, que incrementa la concentración de FDN.

Kudzú fue la especie con menor adaptación a la época seca, con RMS por debajo de 1 t ha-1 hasta los 42 días de edad, potencializándose su respuesta en el mes de mayo (84 días de edad), debido al incremento de la precipitación pluvial. Si bien existen reportes de alta adaptación de esta especie a sequía(23), esta adaptación va en detrimento de su producción de forraje. Aun cuando esta especie registró una proporción de hoja cercana a la de cacahuatillo (por arriba de los $600 \mathrm{~g} \mathrm{~kg}^{-1}$ de MS hasta los 42 días, y alrededor de los $500 \mathrm{~g} \mathrm{~kg}^{-1}$ de MS a partir de los 63 días en ambas épocas), fue superado por clitoria en concentración de proteína en las diferentes edades de rebrote. Existen reportes(22), que señalan la baja concentración the different ages of regrowth. There are reports(22), which point to the low concentration of protein in kudzu, though it has many leaves. However, the degradability of kudzu was intermediate, with the rest of legumes in the dry season, and equal to those recorded for stylo and clitoria, while stylo was higher in the different ages of regrowth in the rainy season.

Clitoria was a species with intermediate response in DMY characters and LSR in both seasons. Although it was not a species with high LSR, recorded the highest concentrations of protein in the dry season, with similar values to that of cacahuatillo at $84 \mathrm{~d}$ regrowth, with values just below $200 \mathrm{~g} \mathrm{~kg}^{-1} \mathrm{DM}$ after $42 \mathrm{~d}$ of regrowth in both seasons. Since many years ago, protein values were reported up to $314 \mathrm{~g} \mathrm{~kg}^{-1} \mathrm{DM}$ in clitoria(23), the higher concentration than in other legumes studied.

Figures 2 and 3 show that between both seasons, the difference was due to DMY (greater in the rainy season), given that the nutritional value of legumes between seasons showed no significant variations. Generally, the DMY of legumes increased and nutritional value decreased with age of regrowth in both seasons, and also after $42 \mathrm{~d}$ in both seasons the decreasing trend was even steeper. Therefore, $42 \mathrm{~d}$ of regrowth of legumes probably should be considered the maximum allowable age for exploitation for animal intake in both periods.

End of english version

de proteína en kudzú, aun cuando presenta una gran cantidad de hojas. Sin embargo, la degradabilidad del kudzú fue intermedia, con respecto al resto de las leguminosas en la época seca, e igual a las registradas en stylo y clitoria, y superior a stylo, en las diferentes edades de rebrote en lluvias.

Clitoria fue una especie con respuesta intermedia en los caracteres RMS y proporción de hoja en 
la biomasa aérea en ambas épocas. Aún cuando no fue una especie con altas proporciones de hojas, registró las mayores concentraciones de proteína en la época seca, con valores semejantes a cacahuatillo a los 84 días de rebrote, y con valores apenas por debajo de los $200 \mathrm{~g} \mathrm{~kg}^{-1}$ de MS a partir de los 42 días de rebrote en ambas épocas del año. Ya desde muchos años atrás, se reportaron valores de proteína de hasta $314 \mathrm{~g} \mathrm{~kg}^{-1}$ de MS en clitoria(23), siendo la concentración más alta que en las otras leguminosas estudiadas.

Finalmente, las Figuras 2 y 3 muestran que entre ambas épocas del año, la diferencia estuvo dada por el RMS (superior en la época lluviosa), dado a que el valor nutritivo de las leguminosas entre épocas no tuvo variaciones importantes. En general, el RMS de las leguminosas fue creciente y el valor nutritivo disminuyó con la edad de rebrote en las dos épocas, presentándose una tendencia a un mayor decrecimiento después de los 42 días en ambas épocas del año. Por lo anterior, una edad máxima de 42 días de rebrote de las leguminosas evaluadas, podría ser considerada para su explotación en el consumo animal en ambas épocas.

\section{LITERATURA CITADA}

1. Bolaños-Aguilar ED, Émile JC, Enríquez-Quiroz JF. Les fourrages au Mexique: ressources, valorisation et perspectives de recherche. Fourrage 2010;204:277-282.

2. Juárez-Hernández J, Bolaños-Aguilar ED, Reinoso M. Contenido de proteína por unidad de materia seca acumulada en pastos tropicales. Época de Nortes. Rev Cub Cienc Agric 2004; 38:423-430.

3. Van Soest PJ. Nutritional ecology of the ruminant; LTTIECA and London: Comstock Publishing Associates, Cornell University Press; 1984.

4. Fulkerson WJ, Neal JS, Clark CF, Horadagoda A, Nandra KS, Barchia I. Nutritive value of forage species grown in the warm temperate climate of Australia for dairy cows: Grasses and legumes. Livest Sci 2007; 107:253-264.

5. Onyeonagu CC, Eze SM. Proximate compositions of some forage grasses and legumes as influenced by season of harvest. Afric J Agric Res 2013;8:4033-4037.

6. Adjolohoun S, Bindelle J., Adandedjan C, Toleba SS, Houinato M, Sinsin B. Variety and environmental effects on crude protein concentration and mineral composition of Arachis pintoi (Kaprovickas \& Gregory) in Benin (West Africa) 2013; 1: 24-28.

7. Hare MD, Tatsapong P, Phengphet S, Lunpha A. Stylosanthes species in north-east Thailand: dry matter yields and seed production. Trop Grassland 2007;41:253-259.

8. Phengsavanh P, Frankow-Lindberg BE. Effect of harvesting interval on biomass yield and nutritive value of five tropical forage legumes (Aeschynomene histrix 'BRA 9690', Canavalia brasiliensis 'CIAT 17009', Stylosanthes guianensis 'ClAT 184' and 'Composite' and Vigna unguiculata 'ClAT 1088-4') in Lao PDR. Grassland Sci 2013;59:80-86.

9. Hiep NV, Wiktorsson H, Man NV. The effect of cutting interval on foliage yield and chemical composition of tropical Kudzu (Pueraria phaseoloides) cultivated as cover-crop in rubber plantation. Livest Res Rural Dev 2008;20(Suppl),: http:// www.Irrd.org/lrrd20/supplement/hiep1.htm Consultado 27 julio 2014.

10. AOAC. Association of Official Analytical Chemist. Orr. of Anal. Chem. 17th ed. Washington, USA. 2000.

11. Van Soest PJ. Nutritional ecology of the ruminant; LTTIECA and London: Comstock Publishing Associates, Cornell University Press; 1994.

12. Orskov ER. Protein nutrition in ruminants 2nd ed. London, England: Academic Press; 1992.

13. Villalobos GC, González VE, Ortega SJA. Técnicas para estimar la degradación de la proteína y materia orgánica en el rumen y su importancia en rumiantes en pastoreo. Téc Pecu Méx 2000; 38:119-123.

14. Ayala BAJ, Rosado RCM, Capetillo LCM, Sandoval CCA. Evaluación del método de lavado de bolsas (manual vs lavadora) en la técnica de degradación ruminal in situ. Téc Pecu Méx 2003; 41:337-342.

15. SAS Institute. User's Guide: Statistics, version 9.3. SAS Inst. Inc., Cary, North Caroline, USA. 2010.

16. Kretschmer $\mathrm{AE}$. Consideraciones sobre factores que afectan la persistencia de leguminosas forrajeras tropicales. CIAT. Pasturas Tropicales 1988; 10:28-33.

17. Pitman WD. Environmental constraints to tropical forage plant adaptation and productivity. In: Sotomayor-Ríos A, Pitman WD editors. Tropical forage plants. Development and use. Boca Raton Florida. USA: CRC Press, 2001:17-23.

18. Perbandt $D$, Fricke $T$, Wachendorf $M$. Effects of changing simulated sky cover on hyperspectral reflectance measurements for dry matter yield and forage quality prediction. Comp Electr Agric 2010; 73:230-239.

19. Evers GW. Forage legumes: Forage quality, fixed nitrogen, or both. Crop Sci 2011;51:403-409.

20. Fenning JO, Quansah C, Sarfo-Kantanka A. Response of three forage legumes to soil moisture stress. J Sci Technol 2009; 29:24-30.

21. Valles B, Castillo E, Hernández T. Producción estacional de leguminosas en Veracruz, México. ClAT. Pasturas Tropicales 1992; 14:32-36.

22. Meléndez NF. Principales forrajes para el trópico. $1^{\text {rst }}$ ed. Tabasco, México: SAGARPA-UPCH; 2012.

23. Bogdan AV. Pastos tropicales y plantas de forraje (Pastos y leguminosas). la ed en español. México DF: AGT Editor SA; 1997. 
24. Volenec JJ, Ourry AA, Joern BC. A role for nitrogen reserves in forage regrowth and stress tolerance. Physiol Plantarum 1996; 97: 185-193.

25. Erice G, Sanz-Sáez GA, Aranjuelo I, Irigoyen JJ, Aguirreolea J, Avice JC, Sánchez-Díaz M. Photosynthesis, N2 fixation and taproot reserves during the cutting regrowth cycle of alfalfa under elevated $\mathrm{CO}_{2}$ and temperature. J Plant Physiol 2011; 168:2007-2014.
26. Dewhurst RJ, Delaby L, Moloney A, Boland T, Lewis E. Nutritive value of forage legumes used for grazing and silage. Irish J Agric Food Res 2009;48: 167-187.

27. Godoy EV, Barrera AA, Vivas MR, Quintana Z), Peña GM, Villota GL, et al. Evaluación fenológica y digestibilidad in vivo de la leguminosa forrajera (Arachis pintoi) en diferentes edades de corte. Ciencia y Tecnología 2012; 5: 716. 